\title{
On the Ontology of Structural Realism
}

\author{
Markus Fischer \\ California State University, Fullerton, California, USA \\ Email: mfischer@fullerton.edu
}

How to cite this paper: Fischer, M. (2019). On the Ontology of Structural Realism. Open Journal of Political Science, 9, 145-162.

https://doi.org/10.4236/ojps.2019.91008

Received: December 23, 2018

Accepted: January 12, 2019

Published: January 15, 2019

Copyright $\odot 2019$ by author(s) and Scientific Research Publishing Inc. This work is licensed under the Creative Commons Attribution International License (CC BY 4.0).

http://creativecommons.org/licenses/by/4.0/

(c) (i) Open Access

\begin{abstract}
Due to its systemic approach, structural realism (or neorealism) can be subsumed under methodological holism, which takes social phenomena to be wholes that cannot be reduced to their parts. The wholes posited by structural realism are the state and the international structure. Recent developments in the philosophy of social science suggest that methodological holism ought to be limited to causal explanation and complemented by ontological individualism, which requires an account of how social wholes derive from individuals. Structural realism lacks such an account because it takes the state as an empirical given, mistaking for a fact what is really a concept in need of deductive derivation from individuals. To bring the theory methodologically up to date, this essay undertakes such a derivation of the state from individuals, proceeding in the deductive manner of political theory. It thus provides structural realism with a methodologically valid ontology, which, in turn, enables the theory to better defend itself against liberal and constructivist critics who reduce the state to a transient phenomenon.
\end{abstract}

\section{Keywords}

Structural Realism, Neorealism, Methodological Holism, Ontological Individualism, State Formation

\section{Introduction}

Kenneth Waltz's structural realism (or neorealism) famously takes a systemic approach in order to explain the behavior of states by the constraining effect of the international structure. Since both the structure and the state are social wholes, that is, collectivities with emergent properties and causal effects of their own, and since Waltz assumes the state to be an empirical entity, he can be said to embrace methodological holism - an approach in the philosophy of social science that gives explanatory and ontological priority to higher-level social entities and their properties. This methodological choice was entirely legitimate 
when Kenneth Waltz made it in the 1970s. Recent developments in the philosophy of social science, however, have convincingly shown that methodological holism ought to be limited to causal explanation and complemented by ontological individualism, that is, an account of how social wholes derive from individuals. Given its holistic predilection, Waltz's theory lacks such an ontological derivation. Rather, it takes the state to exist as a given entity on empirical grounds, thereby hypostasizing the state, that is, mistaking for a concrete fact what is really an abstract concept made up to account for certain behaviors of individuals, such as working together to defend themselves. In other words, Waltz's theory lacks an ontological foundation.

This lack of a proper ontology makes structuralism realism "vulnerable to critics who argue from first principles" (Fischer, 1995: p. 273). For instance, when faced with the liberal claim that international institutions are taking over the functions of the state, structural realists can only reiterate their inductive generalization that states have thus far remained the predominant actors in international affairs. Or, when constructivists ascribe the state to the dominance of state-centered discourses in order to argue that a change in discourse could wither the state, structural realists cannot explain why the state is based on more than discourse. For without an ontological foundation, they cannot deduce the state from human nature in order to make the case that the state-understood abstractly as a self-deciding collective existing under anarchy-is not a historically contingent phenomenon but arises necessarily from the coexistence of security-seeking individuals.

The first part of this essay seeks to explain on the methodological level why Waltz's quite appropriate use of causal-explanatory holism needs now to be complemented by ontological individualism, that is, an account of how the state depends on the existence of individuals. The second part, proceeding in the manner of political theory, deduces the abstract concept of the "realist state" from the abstract concept of "realist man" in order to provide structural realism with its ontological foundation.

\section{Holism, Individualism, and Waltz}

In his first major work, Man, the State, and War, Kenneth Waltz (1954) argued that the recurrence of war could neither be explained from the first image, that is, human nature, nor from the second image, that is, the internal structure of states; rather, war had to be explained from the third image, that is, international anarchy. In his second major work, Theory of International Politics, Waltz (1979) bundled the first and second images together as "reductionist" theories and declared that "reductionist explanations of international politics are insufficient and ... must give way to systemic ones" (p. 37). In the effort to create such a systemic explanation, Waltz posited the existence of interacting units and an international structure, which together make up the international system. Taking the units to consist of states, Waltz (1979) gave the international structure 
two attributes: anarchy—the fact that states exist without a central authority to protect them-and the distribution of capabilities - the fact that states possess varying amounts of power in relation to one another; this structure "acts as a constraint on the system's units. It disposes them to behave in certain ways and not in others" (p. 58).

Waltz's theory can be subsumed under methodological holism, an approach in the philosophy of social science which claims that social wholes exist independently from individuals and have causal effects that cannot be reduced to the properties and actions of individuals. Methodological holism holds for Waltz's theory on two grounds. First, the international structure is a social whole that has causal effects on the behavior and attributes of states. For instance, it is the structural fact that states coexist under anarchy that constrains them to distrust each other and to accumulate power in order to protect themselves; similarly, it is the structural fact that states possess significantly different capabilities that constrains them to recurrently form balances of power. In Waltz's words (1979: p. 98), "although capabilities are attributes of units, the distribution of capabilities across units is not. The distribution of capabilities is not a unit attribute, but rather a system-wide concept". (That Waltz (1954) thought in holistic terms is also suggested by his endorsement of Durkheim's critique of theories that seek to explain social phenomena from the "psychological factor", that is, from the first image (p. 28). Second, Waltz (1979) did not derive the state, which is also a social whole, from individuals but assumed it to exist on empirical grounds: "International structures are defined in terms of the primary political units of an era, be they city states, empires, or nations" (p. 91); and, "so long as the major states are the major actors, the structure of international politics is defined in terms of them" (p. 94). In other words Waltz hypostatized the state, giving a social whole a concrete existence as an entity.

Methodological holism goes back at least to Emile Durkheim, who claimed in 1901 that "A social fact is any way of acting ... capable of exerting over the individual an external constraint; or: which is general over the whole of a given society whilst having an existence of its own, independent of individual manifestations" (p. 59). This approach has been directly opposed by methodological individualism, which ultimately goes back to Hobbes but whose classical champions are F.A. Hayek and Karl Popper. Concerning "the ideas which the popular mind has formed about such collectives as society or the economic system," Hayek (1979) averred in the early 1940s that the social scientist "consistently refrains from treating these pseudo-entities as facts" and "systematically starts from the concepts which guide individuals in their actions" in order to explain social phenomena (p. 64). In 1944, Popper (1957) declared methodological individualism to be the "quite unassailable doctrine that we must try to understand all collective phenomena as due to the actions, interactions, aims, hopes, and thoughts of individual men" (pp. 157-158). These foundational statements of methodological holism and individualism remained influential for the rest of the $20^{\text {th }}$ century, with "the participants in the debate appear[ing] frequently to misun- 
derstand one another and argue at cross-purposes" (Udehn, 2002: p. 480). In consequence, the two approaches appeared irreconcilably opposed, and, since both made plausible claims, it was quite legitimate to use either approach in social science, as Waltz (1979) did with regard to holism when he wrote Theory of International Politics.

However, this methodological choice has been challenged by the emergence of a highly plausible reconciliation between holism and individualism over the last dozen or so years. Drawing on an analogous reconciliation between physicalism and mentalism in the philosophy of mind, R. Keith Sawyer $(2002,2003)$ disaggregated the debate between individualism and holism into a number of salient factors and thus was able to combine the partial truths contained in each approach to formulate a novel doctrine called non-reductive individualism. Accordingly, individualism is ontologically true in the sense that only individuals really exist; for to claim that social wholes exist just as much as individuals "opens one to the criticism of hypostatizing the social group as an entity" (Sawyer, 2002: p. 544). When dismantling a social whole, we are left with only the parts, rather than the parts and some mysterious thing that previously made them into a whole. At the same time, according to Sawyer (2002: p. 554), social scientists "have valid philosophical grounds for developing laws and theories concerning collective phenomena that may not be reducible to laws and theories concerning individuals". The central argument for this irreducibility is "wild disjunction": "for any social property, there is in principle an endless sequence of nomologically possible individual-level states such that although each of them 'realize' or 'implement' the social property, none of them is coextensive with it" (Sawyer, 2002: p. 556). For instance, "a reduction of the group-level natural kind term 'competitive team sport' to natural kind terms of individuals would involve the disjunction [i.e., relationship between distinct alternatives] of all past and potential players' individual properties, in every past and potential competitive team sport, in all of the world's cultures" (Sawyer, 2002: p. 549). Finally, "the extent to which "wild disjunction holds for any given sociological property is an empirical question that must be resolved through empirical study" (Sawyer, 2002: p. 554). In sum, it is legitimate, indeed, necessary to explain social phenomena that empirically suffer from "wild disjunction" by means of social wholes, as long as their ontological dependence on individuals is recognized

Most recently, List and Spiekermann (2013) proposed their own combination of holism and individualism, largely following the trail blazed by Sawyer. Ontologically, List and Spiekermann (2013) hold to individualism for the same reason that Sawyer did: "Methodological individualists are right to remind us that the social world is ultimately the result of many individuals interacting with one another and that any theory that fails to accept this basic premise rests on mysterious metaphysical assumptions" (p. 629). At the same time, List and Spiekermann (2013) allow for the explanation of causal relations by means of social wholes: "Holists are ... right to insist that some social-scientific explanations must employ nonindividualistic terms. It is entirely possible that social proper- 
ties, not individual-level ones, display the most systematic causal relations in some social phenomena" (p. 629. However, "explanatory holism ... does not imply any more radical form of holism that give some kind of metaphysical priority to social structures" (List \& Spiekermann, 2013: p. 629). Hence, one can avail oneself of the explanatory power of social wholes while, at the same time, maintaining that only individuals really exist without entering into a contradiction, for "supervenience [i.e., ontological] individualism ... is fully consistent with causal-explanatory holism" (List \& Spiekermann, 2013: p. 637).

As a result of these advances work, fully-fledged, Durkheimian holism has become indefensible. Since it has been shown that explanatory holism does not imply ontological holism and, moreover, that explanatory holism is compatible with ontological individualism, there is no good reason to hold on to ontological holism. But there is a compelling reason to uphold ontological individualism, namely the fact that the existence of individuals can be directly observed whereas social wholes can only be inferred from their causal effects. Thus, to avoid ascribing a metaphysical existence to social wholes, explanatory holism ought to be combined with ontological individualism.

List and Spiekermann further offer three formal conditions under which the use of causal-explanatory holism is not only admissible but, indeed, required. 1) The social system "admits lower and higher levels of description, associated with different level-specific properties” (List \& Spiekermann, 2013: p. 639). Waltz's three images obviously conform to this condition: man, the state, and the international structure describe political phenomena, attributing distinct properties to each, such as individuals are selfish, states are unitary, and the structure is anarchic. 2) The “system's higher-level properties are determined by its lower-level properties, but can be realized by numerous different configurations of them and hence cannot feasibly be re-described in terms of lower-level properties" (List \& Spiekermann, 1979: p. 639). This condition, which reiterates Sawyer's "wild disjunction" claim, holds true for Waltz's concept of the international structure: anarchy and the distribution of capabilities exist because states exist, but anarchy and the distribution of capabilities exist regardless of the infinite combinations the properties and actions that states can take. The condition holds also true for the state in that explaining the behavior of a state from the actions of the individuals who compose it would have to include all the possible combinations of the specifics of domestic politics past and present: the personalities of the rulers, the constitutional arrangements, the ideologies, the preferences of each voter in the case representative governments, the influence of corporate interests, etc. 3) The "causal relations in which some of the system's higher level properties stand are robust to changes in their lower-level realization" (List \& Spiekermann, 2013: p. 639). This condition practically equates to Waltz's claim that "where similarity of outcomes prevails despite changes in the agents that seem to produce them, one is led to suspect that ... something works as a constraint on the agents. In international politics, system-level forces seem 
to be at work" (1979, p. 39). In sum, causal-explanatory holism is an appropriate methodology for Waltz's theory of international politics.

However, as argued above, such causal-explanatory holism can no longer plausibly stand on its own; in order to keep the twin specter of hypostatization and metaphysics at bay, causal-explanatory holism needs to be complemented with ontological individualism. Applied to Waltz's theory, this argument means that its explanatory account of how the social whole of the international structure causally affects the behaviors of the social wholes of the states needs to be complemented with an ontological account of how the international structure and the state depend on the existence of individuals.

Waltz (1979) actually made a step in this direction when he drew a deductive analogy between the structure of international politics and the structure of the market as explained by microeconomics (pp. 89, 90, 91):

Microeconomic theory describes how an order is spontaneously formed from the self-interested acts and interactions of individual units ... The market arises out of the activities of separate units-persons and firms-whose aims and efforts are direct not toward creating an order but rather toward fulfilling their own internally defined interests ... From the coaction of like units emerges a structure that affects and constrains all of them...

International-political systems, like economic markets, are formed by the coaction of self-regarding units ... Structures emerge from the coexistence of states. No state intends to participate in the formation of the structure by which it and others will be constrained. International-political systems, like economic markets, are individualist in origin, spontaneously generated, and unintended.

Thus, Waltz successfully explained the dependence of the international structure on the coexistence of states. But states are social wholes as well and thus in need of ontological generation from individuals. Yet, rather than taking this further, more demanding step, Waltz assumed the existence of states to be an empirical matter. As a result, Waltz hypostatized the state, taking as a concrete fact what really is an abstract concept. In the words of the philosopher A.N. Whitehead, he committed the "fallacy of misplaced concreteness" (Hayek, 1979: p. 95).

To remedy these shortcomings, an ontology that generates the state from individuals needs to be added to Waltz's theory. As the work of Sawyer and List and Spiekermann has shown, such an addition is not at odds with Waltz's systems approach; rather, it is needed to complement Waltz's systemic explanation of state behavior, as shown in Figure 1.

In a sense, this essay provides a methodological update of Waltz's theory. When he conceived his systemic theory, it had not yet been shown that causal-explanatory holism can and ought to be combined with ontological individualism. Impressed with the explanatory power of systems theory, he quite legitimately applied it to international politics without worrying about the ontological status of the state. However, now that we know that ontological individualism does not require causal-explanatory individualism, it behooves us to combine 


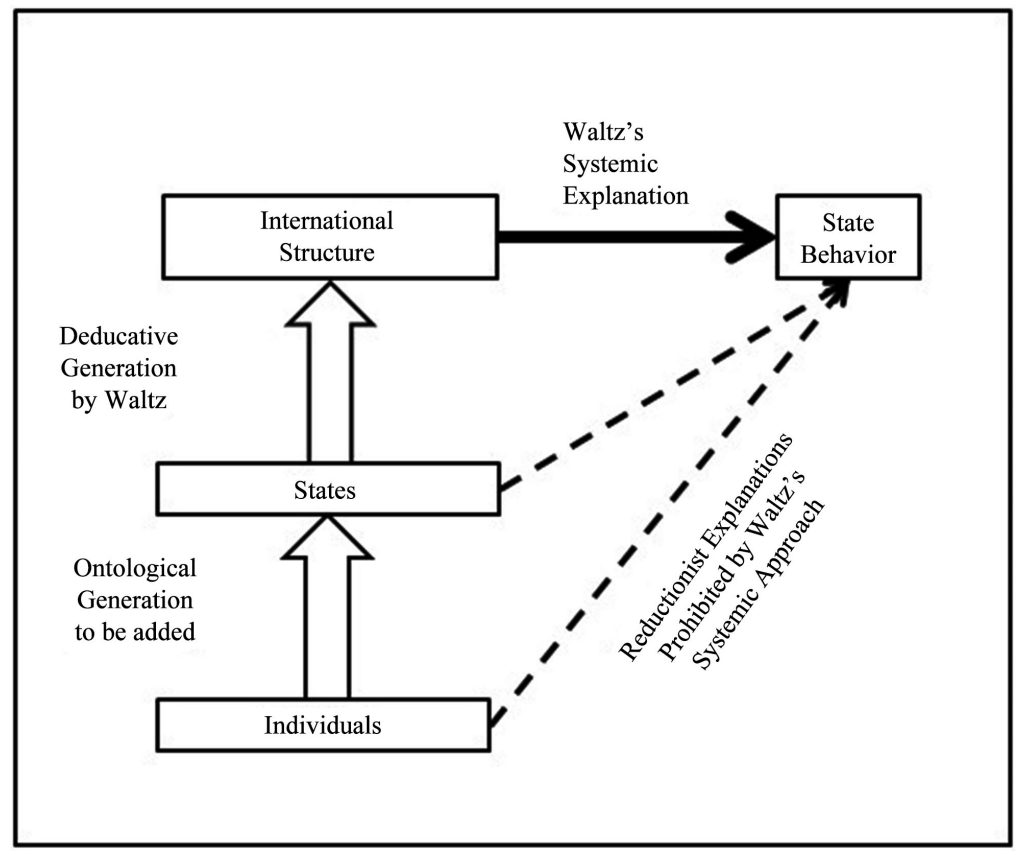

Figure 1. Ontological individualism and Waltz's systemic explanation.

Waltz's causal-explanatory holism with ontological individualism. In other words, we need to undergird Waltz's systemic explanation of the behavior of states with an ontological generation of the state from individuals.

\section{Generating the State}

To show how the state is ontologically caused by individuals is to deduce an abstract concept of the state from an abstract concept of the individual. Such a deduction is not an attempt to create an empirically testable theory of state formation in the manner of social science. Rather, it is an exercise in political theory, wherein propositions on political order are typically derived from assumptions about human nature. Empirically-based accounts of state formation, such as the conflict theories of Oppenheimer (1926), Carneiro (1970), and Tilly (1985), wherein the state results from domination of one group by another, thus do not constrain this deduction.

\subsection{The Realist Boundary Condition}

In order to fit in with structural realism, our deduction of the concept of the state must not introduce assumptions or propositions that could lead to violations of realist tenets of state behavior; for, if we posited state-building actions that, if applied to foreign affairs, would be considered impossible by realism, we would introduce a contradiction. This "realist boundary condition" systematically excludes state formation on the basis of consent, based on both enlightened self-interest and shared beliefs and norms. Consider the liberal account of state formation by means of a social contract. If self-interested individuals who exist under anarchy could make a contract to establish a central power that imposes 
peace among them, then states existing under anarchy should be able to do so as well, that is, cooperatively establish a world state that keeps the peace. For the state is really a number of individuals that keep order among themselves and act collectively toward other states that also consist of individuals, and there is no obvious reason why the first set of individuals can contract among themselves to establish a state but cannot extend their contract to the second set of individuals as well. But a theory that considered states to be capable of abolishing international anarchy by cooperatively establishing supranational entities, such as a world state, could no longer be called realist. (This statement doesn't imply that realism cannot conceive a world state; it implies that such a state can only come about by conquest). The same reasoning holds true for accounts of the state that are based on shared consciousness, such as those offered by constructivism: if a number of individuals could create or abolish a state on grounds of shared beliefs and norms, then they should be able to cooperate with individuals from other states in order to replace international anarchy with a more benign environment.

\subsection{The Hobbesian State of Nature and Realist Man}

To generate the state from the existence of individuals, we start with the assumption that the individuals exist without a state, in other words, that they are in state of nature. To begin with, we assume with Freyberg-Inan (2004: p. 92; 2006: p. 250) that these individuals truly are individuals in the sense of beings with minds of their own who decide for themselves-as opposed to members of a community whose minds are the particular expressions of its collective consciousness. In Hobbes's words (1994: p. 104), "the multitude naturally is not one, but many". With regard to their faculties, individuals are rational in the sense that they try to figure out the appropriate means to their ends (Freyberg-Inan, 2004: p. 94; Freyberg-Inan, 2006: p. 255). (This rationality assumption appears to clash with Waltz's refusal to require states to be rational actors. According to Waltz, it is enough for states to seek to survive and to emulate those that do in order for the international structure to constrain state behavior. But this argument contains a hidden rationality assumption. Let us grant that the first states who find out that increasing power enhances one's chance of survival do so by a process of trial and error, with those who erred falling by the wayside. Those who emulate the behavior of the survivors, on the other hand, do so because they understand that the survivors' behavior is a likely means of survival. In other words, they engage in means-ends rationality.) In Hobbes's words (1994: p. 82), "of the voluntary acts of every man the object is some good to himself". In other words, realist rationality is narrow in the sense that individuals always act in a self-interested way, that is, give priority to their own preferences. Further, this rationality is short-sighted or, to use Hobbes's term (1978: p. 55), suffers from "perturbations of the mind" in the sense that strong passions make individuals cease their deliberation over which means to use and act on the basis of 
the immediate consequences of their actions, as opposed to extending their deliberations to the remote consequences as well. As a result, the rationality of realist man is such that he reliably fails to solve the prisoner's dilemma: fearing death, individuals choose to fight rather than to cooperate even though this decision leads them into a chronic condition of war.

Individuals are further assumed to be equal in the Hobbesian sense that the "weakest has strength enough to kill the strongest, either by secret machination, or by confederacy with others" (Hobbes, 1994: p. 74). For a weak man can indeed kill a strong one by using a weapon if the latter has none or a superior weapon if he does; he can also kill the strong man when he sleeps as he must; and he can overpower the strong man by attacking him in alliance with other weak ones. This equality assumption underscores how vulnerable individuals are in the state of nature. Not even physical strength makes survival a likely outcome; individuals need to join groups for mutual protection.

With regard to preferences, realist man primarily seeks security, but also wealth and recognition. For instance, Thucydides (1989: p. 75) has the Athenians claim that they "were forced to advance [their] dominion to what it is out of the nature of the thing itself, as chiefly for fear, next for honour, and lastly for profit". This claim was echoed by Hobbes, who makes fear of violent death the driving motive in the natural condition (Hobbes, 1978: p. 115), and asserts that "in the nature of man we find three principal causes of quarrel ... the first maketh men invade for gain; the second, for safety; and the third, for reputation" (Hobbes, 1994: p. 76). Finally, there is no need to assume an "animus dominandi," as Morgenthau (1946: p. 195) did, because the quest for security leads individuals to strive for domination.

Based on these assumptions about realist man, we now need to find a deductive logic which enables us to construct the state-again, understood in the abstract sense of a set of individuals that decides for itself how to act under anarchy. Having excluded consent based on self-interest and consent based on beliefs and norms, we are left with coercion as the fundamental cause of the realist state: some individuals force others to obey their commands and thereby establish hierarchies of rulers and ruled, which act as units under the anarchy that continues to exist between them. For the reason that makes individuals seek to form hierarchies, we look to Hobbes's logic of "anticipation":

From this diffidence [i.e., distrust] of one another, there is no way for any man to secure himself so reasonable as anticipation, that is, by force or wiles to master the persons of all men he can, so long till he see no other power great enough to endanger him. (Hobbes, 1994: p. 75)

Under anarchy, individuals have to provide for their own security. Since everyone is capable of killing everyone and since no one can truly know another's intention, fear of violent death makes it rational for everyone to attempt to destroy or subdue everyone else. Although destroying another seems to be the surer way to eliminate the threat he poses, subjugation offers the advantage of gaining a subordinate who then can be commanded to fight on one's side or in 
one's stead; indeed, with the help of the subordinate, it becomes easier to subdue further individuals, until one's security is provided by a fighting force composed of several men. Hobbes (1994: p. 110) calls the result of this subjugation a "commonwealth by acquisition," as when a man "by war subdueth his enemies to his will, giving them their lives on that condition". In other words, one individual vanquishes another in battle and then spares the life of the vanquished on the condition that he henceforth obey the commands of the vanquisher. (Hobbes's equality assumption does not rule out this scenario because the fact that the weakest can kill the strongest either by secret machinations or by confederacy with others implies that the stronger is likely to gain the upper hand in open combat). To organize his subjects into an effective fighting force, the vanquisher then has to prevent them from harming each other and, more generally, keep order among them. In this way, a coercive hierarchy emerges in the state of nature with anarchy remaining intact on its outside. The first state seems to have come into being.

This first deduction faces a serious problem, however. Hobbes's assumption that the weakest can kill the strongest, which we have made for realist man as well, makes it quite unlikely that the vanquisher, who just spared the life of the vanquished, would be able to maintain his rule over the latter, for there are at least three ways in which the vanquished could undo his momentary subjugation. First, he could kill his would-be master at a time when the latter is vulnerable, for instance, when he turns his back or sleeps. Second, when the master combats a third individual, the vanquished could defect and either run away or kill his master with the help of the third individual. Third, the vanquished could run away and hide when commanded to perform some service out of sight of the master. In short, coercive hierarchies cannot be formed by single individuals.

How, then, can the formation of the state be explained on the basis of coercion? The conquering but vulnerable individual needs to be replaced by a conquering group large enough to avoid the three ways in which vanquished individuals can undo their subjugation. For if it is a group that defeats individuals in battle and grants them their lives in exchange for obedience, then the conquering group's members can watch each other's back and take turns at guarding and sleeping. Similarly, some members can be tasked with preventing newly defeated individuals from defecting to the enemy during battle. And, some group members can accompany the new subordinates on missions so that they are never out of sight. In other words, Hobbes's equality assumption holds for individuals but not for groups: the weakest group cannot readily destroy the strongest.

In keeping with the precept of ontological individualism, this coercive group needs to be derived from individuals. But what could cause individuals to cooperate in such a manner that they form a group of sufficient cohesion to fight and subdue others? It cannot be coercion for then the argument would fail on account of infinite regress. Again, it cannot be cooperation for mutual benefit because such cooperation would, if extended to the state, allow for liberal institutions in international relations. And it cannot be shared beliefs and norms be- 
cause such ideas, if extended to the state, would allow for a constructivist shift toward a non-anarchic world.

Hobbes seems to provide a solution when he admits that individuals in the state of nature do not live in isolation but in families that make war on and even conquer one another: "There had never been any time wherein particular men were in a condition of war against one another" (Hobbes, 1994: p. 78). But "in all places where they have lived by small families, to rob and spoil one another has been a trade ... And as small families did then, so now do cities and kingdoms ... for their own security enlarge their dominions ... [and] endeavour as much as they can to subdue or weaken their neighbors" (Hobbes, 1994: pp. 106-107). What holds these families together? According to Hobbes, the "concord" of such families "dependeth on natural lust" and on the "natural inclination of the sexes, one to another, and to their children" (Hobbes, 1994: pp. 77, 129). In addition, a man can attain "sovereign power" over his offspring "by natural force, as when [he] maketh his children to submit themselves and their children to his government, as being able to destroy them if they refuse" (Hobbes, 1994: pp. 109-110). In other words, families are held together by the sexual desire of the parents for each other, by the affection that the parents naturally feel for their children, and by the coercion of the children and grandchildren by the father. However, these causes of cohesion are neither strong nor durable enough for individuals to form a reliable conquering group. First, the sexual bond between father and mother is notoriously weak insofar as human beings, and especially men, are naturally inclined to promiscuity. Second, affection cannot be merely parental if it is to hold the family together beyond the time when the children are grown; the children need to have affection for their parents as well in order to stay with them beyond the time when they could survive on their own. Third, the father can probably coerce his offspring into obedience as long they are children; but once their strength approaches that of adults, Hobbes's equality assumption-that the weakest can kill the strongest-makes it quite unlikely that the father can maintain his rule by force alone. In sum, the Hobbesian family is too small and unstable to form the conquering group that brings into being a coercive hierarchy that can be called a state.

\subsection{Revising Realist Man: Attachment Theory and the Close-Kin Group}

Nonetheless, Hobbes points in the right direction: the only bonds that enable individuals to overcome their mutual fear in the state of nature are those of kinship. More precisely, attachment bonds formed in childhood enable individuals to cooperate with "close kin"-parents, children, brothers, sisters, uncles, aunts, nieces, nephews, and, to a lesser extent, first cousins-even in the absence of a central power that protects them from each other. The close-kin group thus forms the conquering group that successfully subordinates other individuals and forms the first coercive hierarchy or state. 
Attachment theory is a well-established psychological account of the bonds that form when individuals give and receive care in infancy. As averred by Bowlby (1982) and Cassidy and Shaver (2008), bonds arising from attachment are the strongest ties human beings can form, prompting altruistic behavior from otherwise self-seeking individuals. To attain security, an infant instinctually attaches or forms an affective tie to any person who consistently behaves toward him in a care-giving way, that is, engages the infant in lively social interaction and sensitively responds to his signals regarding his needs for safety, physical closeness, and affection. The caregiver becomes attached to the child as well by instinctually developing care-giving bonds. In the natural condition, the group that results from such attachment bonds can be quite sizeable. With grown children maintaining residence in close proximity to their parents and with people having relatively large numbers of children, bonds are formed not only with parents and grandparents but also with nearby uncles, aunts, additional siblings, and, to some extent, first cousins. Further, when women keep having children, they concentrate their care-giving on the nursling and delegate the care of their weaned children to their older siblings, especially girls. Giving and receiving care, siblings thus form attachments that make them intensely loyal to one another. Finally, the permanent neural reorganization caused by care-giving and receiving also gives rise to internalized representations of the attachment figures. As a result, attachment bonds remain intact beyond the point where the offspring has grown up and can provide for itself.

The instinctual nature of attachment rests on the release of a number of hormones, with the most important ones being oxytocin, vasopressin, and prolactin, which lastingly reorganize the brains of both givers and receivers of care (Palmer, 2002). Oxytocin is a chemical messenger released in the brain in response to social contact, especially skin-to-skin contact. Labor, nursing, and holding each other cause oxytocin to surge in both the mother and the baby, creating desire for further contact. Under the early influence of oxytocin, nerve junctions in certain areas of the mother's brain are reorganized, thereby making nurturing behaviors "hard-wired." In the baby's brain, oxytocin positively affects the stress-handling parts. Although no research into the chemistry of sibling nurturance seems to have been done so far, it can be assumed that holding and skin-to-skin contact release oxytocin in care-giving older children and their infant charges as well. A live-in father's oxytocin levels begin to rise during the end of his mate's pregnancy, triggered by pheromones. When the father spends significant amounts of time in contact with his infant, his oxytocin level stays elevated, encouraging him to become more involved in care-giving in a self-perpetuating cycle of behavior and hormonal release, which bonds him to his baby. Again, care-giving male siblings may be assumed to have a similar rise in oxytocin. Elevated oxytocin levels in the father also increase his interest in physical (not necessarily sexual) contact with the mother, thus bonding him to his mate as well. The father's pro-family behavior is further promoted by the hormone vasopressin, which causes the male's brain to reorganize in favor of 
protective behavior when cohabitating with the pregnant mother. Vasopressin also reinforces the father's testosterone-promoted inclination to protect mate and child, while tempering the aggressiveness otherwise caused by testosterone. Prolactin, finally, which is released in healthy people during sleep and in mothers during breast-feeding as well, promotes caregiving behaviors and, over time, directs a corresponding reorganization of the brain. In the father, the prolactin level begins to rise during his mate's pregnancy, but most of the rise occurs after many days of cohabitation with the infant.

The formation of close-kin groups by means of attachment can also be explained on evolutionary grounds. Cooperation with close genetic relatives, including acts of altruism, makes reproductive sense because of the principle of "inclusive fitness" (Hamilton, 1996). Accordingly, genes that disposed individuals to help close kin survive, even at a cost to their own survival and reproductive chances, spread through populations because close kin carry significant shares of an individual's genes: children one half, siblings one half, nieces and nephews a quarter, grandchildren a quarter, and cousins an eighth (Hamilton, 1996: p. 32). With regard to attachment in particular, genes that prompted infants to seek the proximity of caregivers spread through the population because its bearers had a greater chance of survival; genes that prompted mothers, fathers, and siblings to protect and care for infants spread through the population because these genes were inherited by infants who survived in greater numbers. John Bowlby (1982: p. 132), the key architect of attachment theory, explicitly acknowledged the evolutionary basis of altruistic behavior prompted by attachment bonds when he discussed "instinctive behaviour that ... commonly fulfils a function of obvious benefit to some other individual though of no benefit to the performer".

An example is the caregiving behaviour of parents toward their young. Other examples include the helpful behaviour of individuals towards kin other than offspring, notably siblings, nephews, nieces, and sometimes cousins. In every case the behaviour is readily intelligible in terms of gene survival. Offspring carry half the genes of each parent, and, on average, siblings have half their genes in common. (Bowlby, 1982: p. 132)

In other words, the hormones whose release triggers attachment behavior are rooted in our genes. The time over which these genes have evolved amounts to many millions of years because kin-centered nurturing behaviors and the subsequent attachment bonds can be observed not only in humans but also in other primates, whose evolutionary depth is estimated at 65 million years, and also in many mammals, which began to evolve about 200 million years ago.

This inclusion of attachment theory in our argument requires a significant revision of our image of realist man. While it still holds true that realist man distrustfully fails to cooperate with distant kin and non-kin, he must now be assumed to naturally form attachment bonds that enable him to trust and thus to cooperate with close kin. Put in game-theoretical terms, realist man succumbs to the prisoner's dilemma with regard to strangers and distant relatives but is able to overcome the dilemma with regard to close relatives. That realist man has be- 
come a sort of family man who trusts his parents, siblings, and children enough to cooperate with them under anarchy may seem a strange assumption for a theory that otherwise speaks of fear, distrust, and coercion. Yet, it is forced on us by our deductive logic: 1) Because the weakest can kill or escape the strongest, a group is needed to form the first coercive hierarchies. 2) This group cannot be held together by coercion because of infinite regress, and it cannot be held together by self-interested consent or shared beliefs and norms because of the realist boundary condition. 3) Attachment is the only bond that can induce individuals to cooperate under anarchy. 4) Hence, realist man must be assumed to form attachment bonds in infancy.

Obviously, attachment bonds do not extend beyond the close-kin group. In particular, they cannot by themselves hold larger entities, such as states, together since their members are not in the daily care-giving and care-receiving contact that is required for attachment bonds to form. Nor as a rule do attachment bonds extend across the boundaries of states in order to enable international cooperation. Hence, the inclusion of attachment theory in our argument does not violate the realist boundary condition.

\subsection{The Formation of the Realist State}

In the state of nature, individuals do not live in isolation but in close-kin groups held together by attachment bonds. The close-kin group can thus be taken to constitute the group that initiates the formation of the realist state. Seeking to secure itself according to the Hobbesian logic of anticipation, a close-kin group defeats another close-kin group in battle and spares its members' lives on the condition of obeying the conquering group's commands. The conquering group then maintains its rule by tasking some of its members to stand guard at night, to guard the members of the defeated group during fighting or errands, etc., thus solving the Hobbesian equality problem faced by conquering individuals. Moreover, the fact that the members of the defeated group are affectively attached to each other gives the ruling group an additional, highly effective means of coercion: taking hostage some of the defeated kin-group's members and threatening to harm them unless the others obey the ruling group's commands. Having gained subjects in this manner, the ruling group can now use them to generate economic surplus and to fight its battles. Indeed, the newly acquired subjects can be used to acquire additional subjects, thus increasing the conquering group's security and enlarging its dominion.

However, this expansion soon faces a serious problem: the subjects, or the hostages taken from them, will soon become too numerous for the ruling group to coerce personally. To solve this problem, the rulers need to command the subjects to coerce each other, that is, to punish those among them who disobey the rulers' orders. But why would the subjects do this even though they are collectively stronger than the ruling group? Because each one of them has to fear that one or some of the other subjects would obey the command and punish 
him. Never knowing for certain whether the others can be trusted, it is rational for the individuals to obey and thereby to carry out the command to punish disobedient ones (Kavka, 1983). In other words, the subjects face a prisoner's dilemma with regard to disobeying the rulers: even though they would be better off if they all decided to disobey, that is, to cooperate in a rebellion, their uncertainty about each other's intentions makes it rational for each individual to obey, that is, to defect from the would-be rebellion and obey instead. (The existence of attachment bonds between certain subjects complicates this argument insofar as such subjects could expect that their close kin will rather die than kill them for disobedience. However, this seeming mitigation of the prisoner's dilemma cannot be generalized as long as there are at least as many non-close kin among the subjects as there are close kin, for close kin must still fear punishment at the hands of non-close-kin.) In sum, arising from mutual uncertainty about intentions, there is a generalized fear among the subjects that makes it possible for a number of individuals who trust each other on account of attachment bonds to maintain their coercive rule over a relatively larger number of subjects.

For the expansion of this state to continue, however, yet another issue needs to be addressed. As more and more individuals are subdued, there comes a point at which the subjects have become too numerous and geographically too distant for the rulers to communicate their commands directly and to provide the threatening presence that initiates the generalization of fear from mutual uncertainty about intentions. To solve this problem, the rulers need to command a number of readily accessible subjects to specialize in the task of coercion and perform it in their stead. On account of their numbers, arms, and skills, these agents of coercion-who historically might be called armed retainers, vassals, policemen, soldiers, etc-are then capable of coercing a truly large number of subjects over a significant geographic area. As a result, the realist state now contains three ranks: the ruling close-kin group, the agents of coercion, and the ordinary subjects. The agents of coercion receive their commands directly from the rulers and obey them despite the fact that they are more numerous, better armed, and more skilled at fighting because of the fear that one who disobeys might be punished by another. The ordinary subjects obey the agents of coercion despite the fact that they are more numerous because of the fear of being punished by the agents and because of the fear that other ordinary subjects might turn them in or, indeed, lend a punishing hand to the agents of coercion.

Once the state has been established by coercion, epiphenomenal causes of compliance may enter. As the hierarchy endures, the subjects may become accustomed to their rulers and obey in part from habit. Machiavelli (1985: p. 6) makes the paradigmatic case for such habituation with regard to hereditary principalities: "in hereditary states accustomed to the blood line of their prince the difficulties in maintaining them are much less than in new states". Also, consent can enter in the form of exchange relations. The subjects partly obey in exchange for the benefits of order, such as security and therewith the opportunity to engage in economic and other pursuits. In the words of Hobbes (1994: p. 
497), there is a "mutual relation between protection and obedience". The agents of coercion obey not only from fear of each other but also in exchange for the perks they receive. Indeed, ideology in the Marxist sense of ideas that secure the rule of elite and are believed by the subjects, such as morality, law, and religion, can become an epiphenomenal cause of compliance. However, habit, benefits of order, and ideology can do their work only if they are backed up by a credible threat of punishment. Coercion remains the primary cause of compliance. Machiavelli (1996: p. 211) showed this fact with regard to habituation when he argued that "men begin to vary in their customs and to transgress the law" unless "something arises by which punishment is brought back to their memory and fear is renewed in their spirits". Further, the realist state cannot become a rule of law, wherein the rulers are bound to obey the laws that they laid down to keep order among the subjects. Rather, it maintains the doctrine of raison d'état (reason of state), where by the rulers are permitted to violate laws and morality whenever they deem such violation necessary for the maintenance of order. Further, the epiphenomenal causes of compliance can operate only where coercion has mitigated anarchy to the point where individuals feel safe enough to cooperate, that is, within the boundaries of the state. Since anarchy remains unabated outside the state, habit, cooperation, and ideology cannot bring together the subjects of separate states, as liberalism and constructivism variously suggest. Thus, the realist boundary condition has been obeyed.

Individuals that are not close kin may enter the ruling group as the coercion that maintains order is institutionalized. Such institutionalization occurs when the ruling close-kin group lays down laws for the subjects to follow and commands the agents of coercion to enforce them on a regular basis, without having to be commanded to do so in every instance. To maintain order, the laws to be enforced are likely to contain prohibitions against murder, robbery, theft, etc. As a result, the regular enforcement of laws generates not only order but also security within the territory of the state. Importantly, the members of the ruling group enjoy this security as well and thus no longer need to be attached to each other to cooperate. Unattached individuals may thus become rulers as well. Instead of the close-kin group, we can now speak of an elite that rules the realist state.

Our deduction of the realist state from individuals is now complete. It is this state that constitutes the units whose coexistence gives rise to the international structure in Waltz's system. Having shown how the abstract concept of the state depends on the existence of an abstract concept of the individual, we have provided structural realism with an individualistic ontological foundation.

\subsection{The Necessity of the Realist State}

In a coherent deductive argument, the conclusions follow from the premises with necessity. Insofar as our assumptions are plausible and our deductive logic is correct, it can thus be argued that there is necessity in the formation of the realist state. The realist state is an inherent aspect of the human condition inso- 
far as the absence of centralized protection makes it necessary for close-kin groups to secure themselves by subduing others and forming the hierarchic entities we call states. In other words, the anarchic structure that Waltz derives from the coexistence of states actually arises already from the coexistence of close-kin groups. (Contrary to the Hobbesian account of the state of nature, it does not arise from the coexistence of individuals because individuals naturally exist as members of close-kin groups wherein anarchy is suspended due to attachment bonds). Having arisen from the co-existence of close-kin groups, the anarchic structure then constrains the close-kin groups to form states. Once the states are formed, their coexistence, or, more precisely, the threat they pose to each other on account of their capabilities, keeps the anarchic structure in being. Which particular form these states take-tribal chiefdoms, kingdoms, city-states, empire, modern nation-states, etc.-is historically contingent. But the twin fact that states are formed and that the anarchic structure remains to constrain them is necessary and cannot be changed (unless one state would conquerall the others and thereby change the ordering principle from anarchy to hierarchy). In particular, neither the self-interested cooperation claimed by liberalismnor the change of consciousness advocated by constructivism can fundamentally alter this reality.

\section{Conflicts of Interest}

The author declares no conflicts of interest regarding the publication of this paper.

\section{References}

Bowlby, J. (1982). Attachment. London: Hogarth.

Carneiro, R. L. (1970). A Theory of the Origin of the State. Science, 169, 733-738. https://doi.org/10.1126/science.169.3947.733

Cassidy, J., \& Shaver, P. R. (2008). Handbook of Attachment: Theory Research, and Clinical Applications. New York: Guilford Press.

Fischer, M. (1995). Machiavelli's Theory of Foreign Politics. Security Studies, 5, 248-279. https://doi.org/10.1080/09636419508429268

Freyberg-Inan, A. (2004). What Moves Man: The Realist Theory of International Relations and Its Judgment of Human Nature. New York: State University of New York Press.

Freyberg-Inan, A. (2006). Rational Paranoia and Enlightened Machismo: The Strange Psychological Foundations of Realism. Journal of International Relations and Development, 9, 247-268. https://doi.org/10.1057/palgrave.jird.1800093

Hamilton, W. D. (1996). Narrow Roads of Gene Land. Oxford: W.H. Freeman.

Hayek, F. A. (1979). Scientism and the Study of Society. In The Counter-Revolution of Science: Studies on the Abuses of Reason (pp. 17-182). Indianapolis, IN: Liberty Press.

Hobbes, T. (1978). Man and Citizen. Gloucester, MA: Peter Smith.

Hobbes, T. (1994). Leviathan. Indianapolis, IN: Hackett.

Kavka, G. S. (1983). Rule by Fear. Nous, 17, 601-620. https://doi.org/10.2307/2215084 
List, C., \& Spiekermann, K. (2013). Methodological Individualism and Holism in Political Science: A Reconciliation. American Political Science Review, 107, 629-643. https://doi.org/10.1017/S0003055413000373

Machiavelli, N. (1985). The Prince (H. C. Mansfield Jr., Transl.). Chicago, IL: University of Chicago Press.

Machiavelli, N. (1996). Discourses on Livy (Trans., Mansfield, H.C. and Tarcov, N.). Chicago, IL: University of Chicago Press. https://doi.org/10.7208/chicago/9780226500331.001.0001

Morgenthau, H. J. (1946). Scientific Man vs. Power Politics. Chicago, IL: University of Chicago Press.

Oppenheimer, F. (1926). The State. New York: Vanguard.

Palmer, L. F. (2002). The Chemistry of Attachment. API News, 5, 2.

Popper, K. (1957). The Poverty of Historicism. London: Ark Paperbacks.

Sawyer, R. K. (2002). Nonreductive Individualism: Part I-Supervenience and Wild Disjunction. Philosophy of the Social Sciences, 32, 537-559. https://doi.org/10.1177/004839302237836

Sawyer, R. K. (2003). Nonreductive Individualism: Part II-Social Causation. Philosophy of the Social Sciences, 33, 203-224. https://doi.org/10.1177/0048393103033002003

Thucydides (1989). The Peloponnesian War (Transl., Hobbes, T.). Chicago IL: University of Chicago Press. https://doi.org/10.7208/chicago/9780226801056.001.0001

Tilly, C. (1985). Making War and State Making as Organized Crime. In P. B. Evans, D. Rueschemeyer, \& T. Skocpol (Eds.), Bringing the State Back in (pp. 169-191). Cambridge: Cambridge University Press. https://doi.org/10.1017/CBO9780511628283.008

Udehn, L. (2002). The Changing Face of Methodological Individualism. Annual Review of Sociology, 28, 479-507. https://doi.org/10.1146/annurev.soc.28.110601.140938

Waltz, K. N. (1954). Man, the State, and War: A Theoretical Analysis. New York: Columbia University Press.

Waltz, K. N. (1979). Theory of International Politics. New York: Addison Wesley. 